J. Dairy Sci. 97:3707-3714

http://dx.doi.org/10.3168/jds.2013-6725

(C) American Dairy Science Association ${ }^{\circledR}, 2014$.

\title{
Effects of decreasing metabolizable protein and rumen-undegradable protein on milk production and composition and blood metabolites of Holstein dairy cows in early lactation
}

\author{
H. Bahrami-Yekdangi, ${ }^{11}$ M. Khorvash, ${ }^{*}$ G. R. Ghorbani, ${ }^{*}$ M. Alikhani, ${ }^{,}$R. Jahanian, ${ }^{*}$ and E. Kamalian† \\ *Department of Animal Science, Isfahan University of Technology, Isfahan 84156, Iran \\ †Department of Animal Science, University of Gorgan, Gorgan 49138-15739, Iran
}

\begin{abstract}
This study was conducted to evaluate the effects of decreasing dietary protein and rumen-undegradable protein (RUP) on production performance, nitrogen retention, and nutrient digestibility in high-producing Holstein cows in early lactation. Twelve multiparous Holstein lactating cows (2 lactations; $50 \pm 7 \mathrm{~d}$ in milk; $47 \mathrm{~kg} / \mathrm{d}$ of milk production) were used in a Latin square design with 4 treatments and 3 replicates (cows). Treatments 1 to 4 consisted of diets containing 18, $17.2,16.4$, and $15.6 \%$ crude protein $(\mathrm{CP})$, respectively, with the $18 \%$ CP diet considered the control group. Rumen-degradable protein levels were constant across the treatments (approximately $10.9 \%$ on a dry matter basis), whereas RUP was gradually decreased. All diets were calculated to supply a postruminal Lys:Met ratio of about 3:1. Dietary $\mathrm{CP}$ had no significant effects on milk production or milk composition. In fact, $16.4 \%$ dietary CP compared with $18 \%$ dietary CP led to higher milk production; however, this effect was not significant. Feed intake was higher for $16.4 \% \mathrm{CP}$ than for $18 \%$ CP (25.7 vs. $24.3 \mathrm{~kg} / \mathrm{d}$ ). Control cows had greater CP and RUP intakes, which resulted in higher concentrations of plasma urea nitrogen and milk urea nitrogen; cows receiving 16.4 and $15.6 \% \mathrm{CP}$, respectively, exhibited lower concentrations of milk urea nitrogen (15.2 and 15.1 vs. $17.3 \mathrm{mg} / \mathrm{dL}$ ). The control diet had a significant effect on predicted urinary N. Higher CP digestibility was recorded for $18 \% \mathrm{CP}$ compared with the other diets. Decreasing CP and RUP to 15.6 and $4.6 \%$ of dietary dry matter, respectively, had no negative effects on milk production or composition when the amounts of Lys and Met and the Lys:Met ratio were balanced. Furthermore, decreasing CP and RUP to 16.4 and $5.4 \%$, respectively, increased dry matter intake.
\end{abstract}

Received February 22, 2013.

Accepted November 2, 2013.

${ }^{1}$ Corresponding author: ha.bahramiyekdangi@ag.iut.ac.ir or Ht. bahrami@gmail.com
Key words: crude protein, milk production, blood metabolite, rumen-protected methionine

\section{INTRODUCTION}

Dairy cows utilize dietary $\mathrm{CP}(\mathrm{N} \times 6.25)$ with greater efficiency than other ruminants but still excrete about 2 to 3 times more $\mathrm{N}$ in manure than in milk (Broderick, 2003), which results in increased milk production costs and environmental concerns related to $\mathrm{N}$ pollution. However, several studies have reported no improvement in milk and protein production when dietary $\mathrm{CP}$ is increased from 16.1 to $16.7 \%$ to $18.4-18.9 \%$ (Cunningham et al., 1996; Broderick, 2003; Leonardi et al., 2003). It is well established that the amount of protein degraded in the rumen increases with increasing $\mathrm{CP}$ content of the diet. If RDP exceeds microbial needs, then large amounts of $\mathrm{NH}_{3}$ are produced, absorbed into the blood, converted into urea in the liver, and excreted in the urine. In the manure, urinary urea can be rapidly hydrolyzed to $\mathrm{NH}_{3}$ and lost by volatilization into the environment (Muck, 1982). Overfeeding CP also reduces profit margins because of the relatively high cost of protein supplements and the poor efficiency of $\mathrm{N}$ use by dairy cows fed high-protein diets (Broderick, 2003).

The main function of dietary $\mathrm{CP}$ is to supply dairy cows with MP in the form of absorbed AA to meet their requirements for maintenance and production (Broderick, 2003; Schwab et al., 2007). Hence, dairy cow rations should ideally be balanced for AA rather than for protein (Broderick, 2003; Schwab et al., 2007). The goal in protein nutrition should be optimizing $\mathrm{N}$ utilization efficiency, which means minimizing total $\mathrm{N}$ intake while meeting the requirements for milk protein synthesis and, thereby, reducing feeding costs and $\mathrm{N}$ excretion into the environment. As requirements have not been clearly established for all AA, the best alternative is to balance for MP with the right proportions for at least the 2 AA whose requirements are better known; namely, Lys and Met. To meet the requirements for MP without an excess of N, rations must also be balanced for undegradable (RUP) and degradable (RDP) rumen protein. 
Ruminally synthesized microbial CP (MCP), RUP, and, to a much lesser extent, endogenous CP contribute to the passage of MP to the small intestine (NRC, 2001). Metabolizable protein is defined as true protein digested postruminally and AA absorbed by the intestine. If the dietary protein is well balanced, the efficiency of dietary to milk protein conversion will be more than $30 \%$ but when the dietary CP is imbalanced, it will be decreased to $23 \%$ and most of the consumed protein changes to urea (Broderick, 2006; Schwab et al., 2007). In high-producing cows, MCP supplies a lesser portion of the required protein, and significant amounts of the dietary protein must, therefore, escape ruminal degradation to meet protein needs (Broderick, 2006). However, it has been demonstrated that overfeeding of RUP due to imbalanced AA profile reduces the efficiency of MP utilization for milk protein synthesis. The nutritive value of MP for dairy cows is determined by its profile of essential AA (Broderick, 2006).

Methionine and lysine have been most often identified as the 2 most limiting AA in lactating dairy cows (Schwab et al., 2007). This is largely because of their low concentrations in dietary protein compared with their concentrations in milk and ruminally synthesized MCP. NRC (2001) recommends concentrations of 7.2 and $2.4 \%$, respectively, for Lys and Met in MP for maximal use of MP for milk protein production. It is difficult to achieve these concentrations in practice; hence, the practical concentrations of 6.6 and $2.2 \%$ recommended for Lys and Met in MP (Schwab et al., 2003). These can be generally achieved by using a combination of highLys protein supplements (e.g., blood, fish, and soybean meals) or a rumen-protected Met (RPM) product that not only limits RUP intake to the required levels but also maintains constant RDP and fermentable carbohydrate levels to fix the MCP produced (Schwab et al., 2007). If an RPM product is not available or cannot be used, a blend of RUP supplements will be required to achieve the desired ratio of 3:1 for Lys:Met in MP, which will then lower the concentrations of both Lys and Met in MP (Schwab et al., 2003). The objective of the present study was to investigate the effects of reduced dietary $\mathrm{CP}$ and RUP levels on production performance, blood metabolites, nutrient digestibility, and $\mathrm{N}$ utilization in high-producing Holstein cows in early lactation when $\mathrm{RDP}$ is kept constant and Lys:Met is balanced.

\section{MATERIALS AND METHODS}

\section{Cows and Experimental Diets}

This study was conducted using 12 high-producing multiparous Holstein cows (second parity, $50 \pm 7$ DIM, and milk production of $47 \pm 4 \mathrm{~kg} / \mathrm{d}$ ). Cows were ran- domly assigned to 1 of 4 diet sequences in a complete $4 \times 4$ Latin square design with 4 treatments and 3 squares. Before feeding the cows, all feed ingredients were analyzed for chemical composition (Table 1). The cows were then fed a balanced TMR formulated according to the NRC (2001) model (Table 2). The duration of each experimental period was $21 \mathrm{~d}$, with $16 \mathrm{~d}$ for diet adaptation and $5 \mathrm{~d}$ for data collection. Cows were held in separator stalls for the duration of the experiment, had free access to water, and were weighed at the beginning (d 1) and end of each period (d 21). The daily $\mathrm{CP}$ requirement of large-breed cows (BW of 680 $\mathrm{kg}$ at 90 DIM) for $45 \mathrm{~kg} / \mathrm{d}$ with minimal BW change as predicted by the NRC (2001) model was $17.9 \%$. The cows fed a diet containing $18 \% \mathrm{CP}$ were used as the control group. Dietary treatments were treatment 1, a TMR containing 18\% CP (7\% RUP based on DM), treatment 2, a TMR that contained $17.2 \%$ CP $(6.2 \%$ RUP based on DM), treatment 3, a TMR containing $16.4 \% \mathrm{CP}$ (5.4\% RUP based on DM), and treatment 4, a TMR that contained $15.6 \%$ CP (4.6\% RUP based on DM). The RDP level was kept constant across the diets (almost $11 \%$ on a DM basis), and a part of RUP was replaced with corn silage and alfalfa to maintain fixed levels of microbial protein in all diets. Fat powder (Palmak, Gujarat, India) was supplemented so that the diets had the same amount of $\mathrm{NE}_{\mathrm{L}}$ (Tables 2 and 3). Decreasing dietary RUP gradually led to declining amounts of MP, especially from RUP sources. Predicted microbial protein synthesis remained invariable due to the constant level of RDP supplemented with urea (Table 3). Ruminally protected methionine (Mepron, Degussa Corp., Kennesaw, GA) was used to meet the requirements (59 $\mathrm{g} / \mathrm{d}$ in MP) based on the NRC (2001) model (Table 3). All diets were formulated to contain a postruminally available Lys:Met ratio of approximately $3: 1$, as recommended by Clark et al. (1992) and the Mepron dairy ration evaluator (version 2.1, 1999; Degussa Huls Corp., Bannockburn, IL).

\section{Sample Collection and Analysis}

The experimental diets were fed as TMR twice daily at approximately 0800 and $1600 \mathrm{~h}$. The feed offered was adjusted daily to yield 5 to $10 \%$ orts. Samples of individual feeds and orts (about $0.5 \mathrm{~kg}$ ) were taken daily and stored at $-20^{\circ} \mathrm{C}$. Weekly composite samples from feeds and orts were dried at $60^{\circ} \mathrm{C}$ for $48 \mathrm{~h}$, and the asfed composition of the diets was adjusted every week. Weekly feed composites were ground through a 1-mm screen (Wiley mill, Arthur H. Thomas, Philadelphia, $\mathrm{PA}$ ) and analyzed for $\mathrm{DM}$ at $105^{\circ} \mathrm{C}$ (AOAC, 1980), ash (AOAC International, 2000; method 942.05), NDF (Van Soest et al., 1991), CP (AOAC International, 
Table 1. Chemical composition of feed ingredients based on $\mathrm{DM}^{1}(\%)$ and for RUP and RDP based on CP (\%) expressed as means

\begin{tabular}{|c|c|c|c|c|c|c|c|c|c|c|c|}
\hline Ingredient & \multicolumn{11}{|c|}{ Composition, \% of DM } \\
\hline Alfalfa hay & 93.2 & 13.5 & 73.7 & 26.2 & 55.7 & 38.8 & 3.4 & 8.5 & 18.7 & 0.19 & 0.73 \\
\hline Beet pulp & 96.8 & 10.3 & 73.9 & 26.0 & 48.0 & 22.0 & 1.0 & 5.6 & 34.9 & 0.12 & 0.48 \\
\hline Ground barley & 89.5 & 10.7 & 60.4 & 39.5 & 22.5 & 5.0 & 2.0 & 4.0 & 60.7 & 0.16 & 0.37 \\
\hline Ground corn & 89.8 & 8.4 & 60.7 & 39.2 & 11.0 & 5.2 & 3.9 & 5.5 & 71.2 & 0.16 & 0.25 \\
\hline Canola meal & 92.8 & 37.3 & 69.4 & 30.5 & 33.5 & 18.7 & 3.3 & 8.2 & 17.6 & 0.68 & 1.94 \\
\hline Cottonseed, whole with lint & 94.4 & 19.3 & 70.0 & 29.9 & 52.9 & 37.0 & 19.3 & 3.9 & 4.5 & 0.26 & 0.79 \\
\hline Corn gluten meal & 93.9 & 56.9 & 40.0 & 59.9 & 13.8 & 7.2 & 1.8 & 5.0 & 22.3 & 1.42 & 0.79 \\
\hline Fish meal & 95.6 & 60.1 & 34.2 & 65.8 & 6.5 & 8.5 & 17.7 & 15.0 & 0.6 & 1.61 & 1.82 \\
\hline
\end{tabular}

${ }^{1}$ Proximate analysis (CP, NDF, ADF, ash, fat, and NFC), degradability of protein (\% of CP) by Cornell Net Carbohydrate and Protein System (CNCPS) method (Sniffen et al., 1992; Licitra et al., 1996), amino acid profile by amino acids analyzer for concentrate ingredients, and near infrared spectroscopy for forage ingredients.

2000; method 990.03), and ether extract (AOAC, 1990; method 920.39) (Table 2). Nonstructural carbohydrate content $(\%$ of $\mathrm{DM})$ of diets was calculated as follows: $100-(\mathrm{NDF} \%+\mathrm{CP} \%+$ ether extract $\%+\operatorname{ash} \%)$. Chemical compositions of the principal dietary ingredients were analyzed (Table 1), and sufficient amounts of all ingredients were stored for gradual use. Corn silage was used freshly and sampled on a weekly basis for DM content.

Cows were milked 3 times daily and milk weights were recorded at each milking event. On d 16 to 21 of each period, milk samples were collected and analyzed for fat, true protein, lactose, SNF, TS, and MUN content by Milkoscan (Foss Electric, Hillerød, Denmark; AOAC International, 1996).

On d 19 of each period, samples of rumen fluid from each cow were collected by stomach tube 3 to 4 $\mathrm{h}$ after morning feeding. The $\mathrm{pH}$ of the samples was measured immediately, and $20 \mathrm{~mL}$ of the rumen fluid was acidified with $0.4 \mathrm{~mL}$ of $50 \%$ (vol/vol) sulfuric acid and stored at $-20^{\circ} \mathrm{C}$ for later analysis of $\mathrm{NH}_{3}$ (Broderick et al., 2004).

Table 2. Feed ingredients of experimental $\operatorname{diets}^{1}$ based on DM $(\%)$

\begin{tabular}{|c|c|c|c|c|}
\hline \multirow[b]{2}{*}{ Ingredient } & \multicolumn{4}{|c|}{ Dietary CP, $\%$ of DM } \\
\hline & 18 & 17.2 & 16.4 & 15.6 \\
\hline Alfalfa hay & 15.3 & 15.8 & 16.3 & 16.6 \\
\hline Corn silage & 19.4 & 20.4 & 21.4 & 22.4 \\
\hline Beet pulp & 3.8 & 3.8 & 3.8 & 3.8 \\
\hline Ground barley & 17.7 & 17.7 & 17.7 & 17.7 \\
\hline Ground corn & 17.7 & 17.7 & 17.7 & 17.8 \\
\hline Soybean meal & 6.2 & 6.2 & 6.2 & 6.2 \\
\hline Soybean extruded & 5.5 & 5.5 & 5.5 & 5.5 \\
\hline Canola meal & 1.1 & 1.1 & 1.1 & 1.1 \\
\hline Cottonseed whole & 3.3 & 3.3 & 3.3 & 3.3 \\
\hline Corn gluten meal & 5.2 & 3.8 & 1.9 & 0.2 \\
\hline Fish meal & 1.9 & 1.4 & 0.8 & 0.2 \\
\hline Fat powder & 0.4 & 0.7 & 1.5 & 2.3 \\
\hline Sodium bicarbonate & 0.8 & 0.8 & 0.8 & 0.8 \\
\hline Magnesium oxide & 0.2 & 0.2 & 0.2 & 0.2 \\
\hline Calcium carbonate & 0.6 & 0.6 & 0.6 & 0.6 \\
\hline Dicalcium phosphate & 0.2 & 0.2 & 0.2 & 0.2 \\
\hline White salt & 0.3 & 0.3 & 0.3 & 0.3 \\
\hline Mineral and vitamin premix ${ }^{2}$ & 0.4 & 0.4 & 0.4 & 0.4 \\
\hline Rumen-protected methionine (Mepron) ${ }^{3}$ & 0.00 & 0.03 & 0.05 & 0.07 \\
\hline Urea $281 \%$ CP & 0.00 & 0.07 & 0.22 & 0.33 \\
\hline Total, \% & 100 & 100 & 100 & 100 \\
\hline
\end{tabular}

${ }^{1}$ Treatments 1 to 4 consisted of TMR containing 18, 17.2, 16.4, and $15.6 \%$ CP, respectively.

${ }^{2}$ Composition: $195 \mathrm{~g} / \mathrm{kg}$ of Ca, $21 \mathrm{~g} / \mathrm{kg}$ of $\mathrm{Mg}, 2.2 \mathrm{~g} / \mathrm{kg}$ of $\mathrm{Mn}, 0.3 \mathrm{~g} / \mathrm{kg}$ of Zn, $0.3 \mathrm{~g} / \mathrm{kg}$ of Cu, $0.12 \mathrm{~g} / \mathrm{kg}$ of I, $0.1 \mathrm{~g} / \mathrm{kg}$ of $\mathrm{Co}, 600,000 \mathrm{IU} / \mathrm{kg}$ of vitamin A, 200,000 IU $/ \mathrm{kg}$ of vitamin D, and $0.2 \mathrm{~g} / \mathrm{kg}$ of vitamin E, $2.5 \mathrm{~g} /$ $\mathrm{kg}$ of antioxidant.

${ }^{3}$ Degussa Corp. (Kennesaw, GA). 
Table 3. Chemical composition and predicted values of MP, Lys, Met, and Lys:Met ratios in experimental $\operatorname{diets}^{1}$

\begin{tabular}{|c|c|c|c|c|}
\hline \multirow[b]{2}{*}{ Chemical composition } & \multicolumn{4}{|c|}{ Dietary CP, $\%$ of DM } \\
\hline & 18 & 17.2 & 16.4 & 15.6 \\
\hline $\mathrm{NE}_{\mathrm{L}},{ }^{2} \mathrm{Mcal} / \mathrm{kg}$ of DM & 1.7 & 1.7 & 1.7 & 1.7 \\
\hline $\mathrm{CP}, \%$ of $\mathrm{DM}$ & 18 & 17.2 & 16.4 & 15.6 \\
\hline RDP, $\%$ of DM & 10.9 & 10.8 & 10.7 & 10.9 \\
\hline RUP, $\%$ of DM & 7.1 & 6.3 & 5.5 & 4.7 \\
\hline $\mathrm{MP}^{3} \mathrm{~g} / \mathrm{d}$ & 2,867 & 2,711 & 2,533 & 2,366 \\
\hline MP from bacteria, ${ }^{3} \mathrm{~g} / \mathrm{d}$ & 1,176 & 1,159 & 1,138 & 1,120 \\
\hline MP from RUP ${ }^{3} \mathrm{~g} / \mathrm{d}$ & 1,690 & 1,552 & 1,394 & 1,246 \\
\hline Lys, ${ }^{3} \mathrm{~g}$ of MP & 189.1 & 184.4 & 179.4 & 174.6 \\
\hline Met, ${ }^{3} \mathrm{~g}$ of MP & 59 & 59.2 & 59.3 & 59.2 \\
\hline Lys, ${ }^{3} \%$ of MP & 6.6 & 6.8 & 7.1 & 7.4 \\
\hline Met, ${ }^{3} \%$ of MP & 2.0 & 2.2 & 2.3 & 2.5 \\
\hline Lys:Met ${ }^{3}$ & 3.2 & 3.1 & 3.0 & 2.9 \\
\hline Ether extract, $\%$ of DM & 5.3 & 5.6 & 6.2 & 6.8 \\
\hline $\mathrm{NDF}, \%$ of DM & 31.8 & 32.3 & 32.7 & 33 \\
\hline $\mathrm{ADF}, \%$ of $\mathrm{DM}$ & 18.0 & 18.3 & 18.6 & 18.9 \\
\hline $\mathrm{NFC}^{4} \%$ of DM & 38.3 & 38.4 & 38.3 & 38.3 \\
\hline $\mathrm{Ca}, \%$ of $\mathrm{DM}$ & 0.81 & 0.81 & 0.81 & 0.81 \\
\hline $\mathrm{P}, \%$ of $\mathrm{DM}$ & 0.43 & 0.43 & 0.43 & 0.43 \\
\hline
\end{tabular}

On $20 \mathrm{~d}$ of each period, blood samples were collected 3 to $4 \mathrm{~h}$ after morning feeding from the coccygeal vessels using an evacuated tube with anticoagulant (EDTA). Blood samples were centrifuged at $3,000 \times g$ for 15 min. Plasma samples were separated and stored in plastic tubes frozen at $-20^{\circ} \mathrm{C}$ until analysis. Concentrations of plasma glucose, triglyceride, NEFA, BHBA, total protein, albumin, globulin, plasma urea nitrogen, and aspartic succinyltransferase were measured using a serum spectrophotometer (UNICCO, 2100, Zistchemi Co., Tehran, Iran).

Eating and ruminating activities of the cows were visually monitored in all treatments every 5 min over 24 -h on d 21 of each period. Eating and ruminating activities were noted every 5 min and each activity was assumed to persist for the entire 5-min interval. The parameters observed included the time spent standing (resting; i.e., neither eating, nor drinking, nor ruminating), eating, and ruminating (standing and lying). Activities were calculated by dividing the total number of minutes by the mean of each variable measured.

On d 16 to 21 of each period, feces samples were taken from each cow after the morning feeding and acidinsoluble ash (AIA) was used as an internal marker to determine the apparent digestibility of nutrients. Feed, refusals, and fecal samples were collected (Elliot et al., 1981) and analyzed for AIA using a modification of the $2 N \mathrm{HCl}$ procedure of Van Keulen and Young (1977). Digestibility by AIA was calculated as the ratio of AIA in feed (corrected for refusals) and feces (Van Soest, 1994).

\section{Statistical Analysis}

All data were analyzed as a $4 \times 4$ Latin square design using Proc Mixed of SAS (version 8.2, 2001; SAS Institute Inc., Cary, NC). Model sums of squares included mean, cow (within square), square, period, treatment (effect of diet), square $\times$ treatment and period $\times$ treatment interactions, as well as overall error. All the variables were considered to be fixed, except cow (within square) and overall error, which were taken to be random. The interaction term square in the square $x$ treatment was removed from the model when $P>0.25$. The first-order autoregressive covariance structure [AR (1)] and the MIXED model were used for data analysis:

$$
\begin{aligned}
Y_{i j k l}=\mu & +T_{i}+A_{j}+P_{k}+(T \times P)_{i k} \\
& +b_{1}(\text { Pmilk })+e_{i j k l},
\end{aligned}
$$

where $y_{i j k l}=$ each observation, $\mu=$ overall mean, $T_{i}=$ fixed effect of treatment, $A_{j}=$ random effect of cow, $P_{k}=$ fixed effect of period, $(T \times P)_{i k}=$ interaction of period and treatment, $b_{1}=$ covariate factor of initial milk production (Pmilk), and $e_{i j k l}=$ random error term.

\section{RESULTS AND DISCUSSION}

The treatment with dietary $\mathrm{CP}$ of $16.4 \%$ had a linearly significant effect $(P<0.05)$ on DMI (Table 4$)$, whereas the other treatments had no significant effect 
Table 4. Effects of decreasing CP (from RUP sources) on milk production, milk composition, and feed efficiency

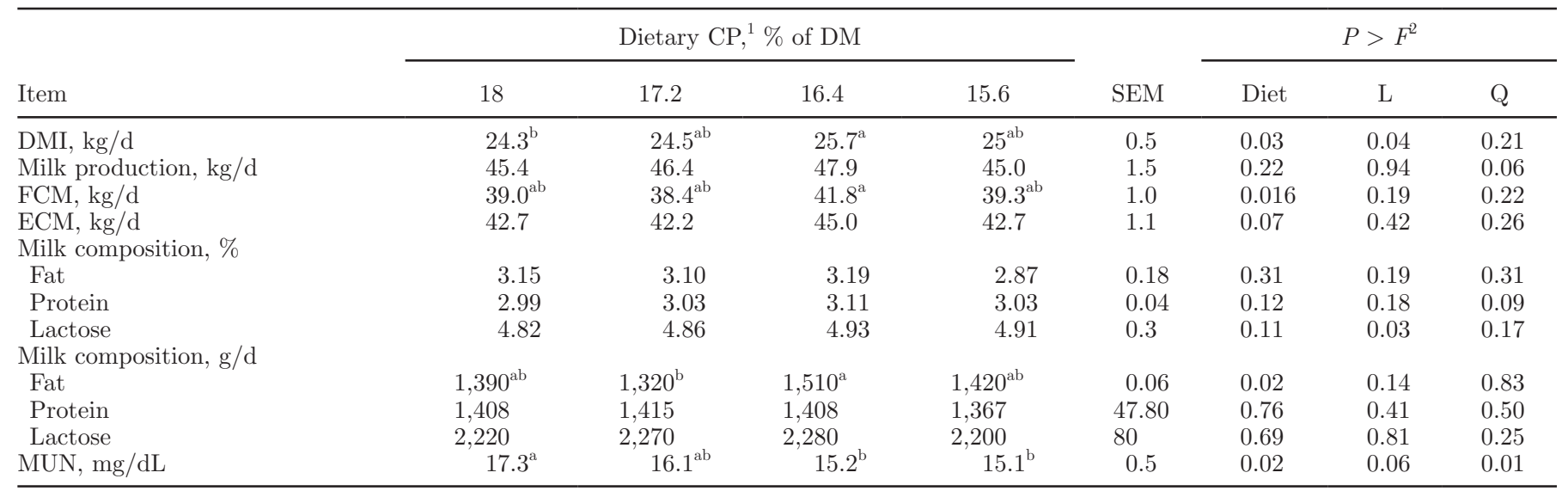

${ }^{\mathrm{a}, \mathrm{b}}$ Least squares means within a row with different superscripts differ $(P<0.05)$.

${ }^{1}$ Treatments 1 to 4 consisted of TMR containing 18,17.2, 16.4, and $15.6 \% \mathrm{CP}$, respectively.

${ }^{2}$ Probability of a significant effect of dietary CP or of a linear (L) or quadratic (Q) effect of dietary CP.

$(P>0.05)$. Milk production and composition were not affected by the experimental diets (Table 4); however, milk production for 17.2 and $16.4 \%$ dietary $\mathrm{CP}$ diets increased numerically $(P>0.05)$. Dietary treatment 3 $(16.4 \% \mathrm{CP})$ had a significant effect on ECM and milk fat content $(\mathrm{g} / \mathrm{d} ; P<0.05)$. In addition, the lower protein diets $(17.2,16.4$, and $15.6 \%$ dietary $\mathrm{CP})$ did not limit milk yield, milk fat, or milk protein compared with the control group (18\% dietary CP). These results were paralleled by quadratically increased $\mathrm{CP}$ digestibility and numerically increased $\mathrm{N}$ efficiency (milk $\mathrm{N}: \mathrm{N}$ intake). In fact, decreased RUP with a reasonable supply of Lys and Met and constant levels of RDP, fermentable carbohydrate, and MP from rumen bacteria (Table 3) and the increased MCP portion of MP due to the balanced AA profile not only increased the efficiency of MP (Schwab et al., 2003), but also failed to have any negative effects on milk yield and FCM. These findings are consistent with those of other studies that reported no changes in production performance when dietary CP varied from 16.7 to $18.4 \%$ (Davidson et al., 2003), from 16.4 to 20.4\% (Mulligan et al., 2004), from 16.4 to $18.0 \%$ (Wattiaux and Karg, 2004), and from 14.6 to $18.3 \%$ (Castillo et al., 2001). In contrast, one study reported significant differences in milk yield or composition with dietary alteration in CP from 13.1 to $17.0 \%$ (Frank and Swesson, 2002). Dietary protein up to $15 \%$ has been reported to affect milk production; however, no such effect is observed when it is increased beyond $17 \%$ (Groff and $\mathrm{Wu}, 2005$ ), although only minimal effects have been reported on milk fat and protein concentration (Sutton, 1989).

The NRC (2001) model predicted an $\mathrm{NE}_{\mathrm{L}}$-limited milk yield of $42.2 \mathrm{~kg} / \mathrm{d}$ for all 4 experimental diets but MP-limited milk yields of 45.1, 42, 38.3, and $34.8 \mathrm{~kg} / \mathrm{d}$ respectively, were predicted by the same model for the diets containing 18, 17.2, 16.4, and $15.6 \% \mathrm{CP}$. Responses in yields of milk and $\mathrm{FCM}$ indicated that $\mathrm{NE}_{\mathrm{L}}, \mathrm{MP}$, and AA supplies were greater than those predicted by NRC (2001) for the lower CP and RPM-supplemented diets. Assuming that Met limited production, the predicted supply of digestible Met was more than adequate for $18 \%$ dietary CP and, because of the added RPM, for the 3 lower CP diets as well (Table 3). Supplying adequate AA levels probably accounted for the milk production observed in this trial. If we assume that the optimal ratio of absorbed Lys:Met is 3.0 (NRC, 2001) and that Lys is the second-limiting essential AA (Schwab et al., 1992), then the 3 lower CP diets with Lys:Met ratios of 3:1 had the most favorable AA patterns and supplies in the current trial. On the basis of the NRC (2001) model, Met supply was adequate in all treatments and Lys was higher than the amount predicted by the NRC (2001) model. With gradually decreasing RUP, the estimated supply of Lys gradually decreased (with decreasing MP) for the 17.2 and $16.4 \%$ $\mathrm{CP}$ diets. The estimated supply of Lys at $174.6 \mathrm{~g} / \mathrm{d}$ was sufficient for the $15.6 \% \mathrm{CP}$ diet according to the NRC (2001) model (Table 3), resulting in no decline in milk yield across the dietary treatments containing 18 to $15.6 \%$ CP (Table 4 ). When EAA are absorbed in the profile as required by the animal, the efficiency of EAA in using protein is maximized and the requirement for total absorbed AA is reduced (Schwab et al., 2004; Broderick et al., 2008).

The effect of dietary CP level on MUN content is shown in Table 4 . The MUN values decreased quadratically $(P<0.05)$ with lower $\mathrm{CP}$ and were significantly affected by dietary treatment, with the lowest value for the 15.6 and $16.4 \% \mathrm{CP}$ diets, followed by the $17.2 \%$ 
Table 5. Effects of decreasing CP (from RUP sources) on feed efficiency, BCS, BW change, and eating, rumination, and chewing time

\begin{tabular}{|c|c|c|c|c|c|c|c|c|}
\hline Item & \multicolumn{4}{|c|}{ Dietary $\mathrm{CP},{ }^{1} \%$ of $\mathrm{DM}$} & SEM & \multicolumn{3}{|c|}{$P>F^{2}$} \\
\hline $\mathrm{FER}^{3}$ & 1.8 & 1.9 & 1.8 & 1.8 & 0.07 & 0.75 & 0.48 & 0.44 \\
\hline ECM:DMI & 1.7 & 1.7 & 1.7 & 1.7 & 0.05 & 0.91 & 0.67 & 0.97 \\
\hline Mean BCS & 3.0 & 3.0 & 3.0 & 2.9 & 0.04 & 0.26 & 0.60 & 0.24 \\
\hline BCS change & 0.09 & -0.02 & 0.11 & 0.07 & 0.06 & 0.22 & 0.72 & 0.51 \\
\hline \multicolumn{9}{|l|}{ Time/day, min } \\
\hline Rumination & 455.4 & 475.4 & 492.9 & 459.6 & 21.34 & 0.29 & 0.65 & 0.08 \\
\hline Eating & 360.8 & 366.2 & 365.8 & 347.1 & 12.70 & 0.40 & 0.30 & 0.18 \\
\hline Resting & 529.2 & 489.2 & 454.2 & 520.8 & 42.68 & 0.29 & 0.65 & 0.08 \\
\hline $\mathrm{TCA}^{4}$ & 816.2 & 841.7 & 858.7 & 806.7 & 25.09 & 0.16 & 0.88 & 0.09 \\
\hline \multicolumn{9}{|c|}{ Time, min $/ \mathrm{kg}$ of DMI } \\
\hline Rumination & 18.9 & 19.5 & 19.2 & 18.7 & 0.99 & 0.86 & 0.38 & 0.50 \\
\hline
\end{tabular}

${ }^{1}$ Treatments 1 to 4 consisted of TMR containing 18, 17.2, 16.4, and $15.6 \% \mathrm{CP}$, respectively.

${ }^{2}$ Probability of a significant effect of dietary $\mathrm{CP}$ or of a linear (L) or quadratic (Q) effect of dietary CP.

${ }^{3} \mathrm{FER}$ (feed efficiency ratio) = milk production $(\mathrm{kg} / \mathrm{d}): \mathrm{DMI}(\mathrm{kg} / \mathrm{d})$.

${ }^{4}$ Total chewing activity (sum of eating and rumination time).

CP diet, and the highest for the $18 \%$ CP diet. This observation is consistent with those reported elsewhere (Davidson et al., 2003; Groff and Wu, 2005; Promkot and Wanapat, 2005), whereas Flis and Wattiaux (2005) found that a $1 \%$ change in dietary $\mathrm{CP}$ level did not lead to any significant changes in MUN content. Research and field experience have indicated that Met is most often the first-limiting and Lys the second-limiting AA for milk protein production (Schwab et al., 2007). Metabolizable protein efficiency has reportedly been improved by supplying adequate amounts of Lys and Met, and maintaining a desirable Lys:Met ratio (Schwab et al.,
2007), resulting in decreased urea production and MUN levels (Wattiaux and Karg, 2004; Schwab et al., 2007).

No significant treatment effects $(P>0.05)$ were observed on mean BW, mean BCS, BW changes, or BCS changes (Table 5). These results are consistent with those reported by Davidson et al. (2003), who observed no changes when dietary $\mathrm{CP}$ level varied from 16.8 to $19.4 \%$.

Plasma parameters (Table 6) did not exhibit any significant differences with either reduced dietary $\mathrm{CP}$ or RUP $(P>0.05)$. Plasma urea concentrations were numerically higher $(P>0.05)$ in cows consuming high-

Table 6. Effects of decreasing CP (from RUP sources) on blood metabolites and rumen parameters

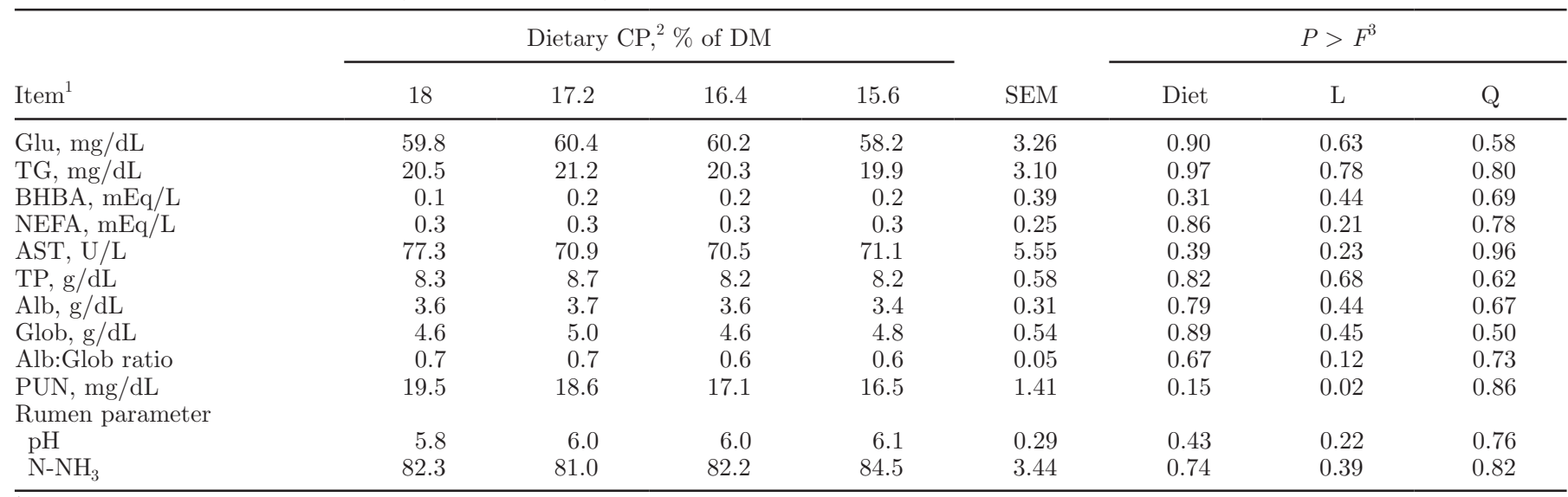

${ }^{1} \mathrm{Glu}=$ glucose $\mathrm{TG}=$ triglyceride; $\mathrm{AST}=$ aspartic succinyltransferase; $\mathrm{TP}=$ total protein; Alb $=$ albumin; Glob $=$ globulin; PUN $=$ plasma urea N.

${ }^{2}$ Treatments 1 to 4 consisted of TMR containing 18, 17.2, 16.4, and $15.6 \% \mathrm{CP}$, respectively.

${ }^{3}$ Probability of a significant effect of dietary CP or of a linear (L) or quadratic (Q) effect of dietary CP 
Table 7. Effects of decreasing CP (from RUP sources) on N retention, N efficiency, and apparent digestibility of nutrients

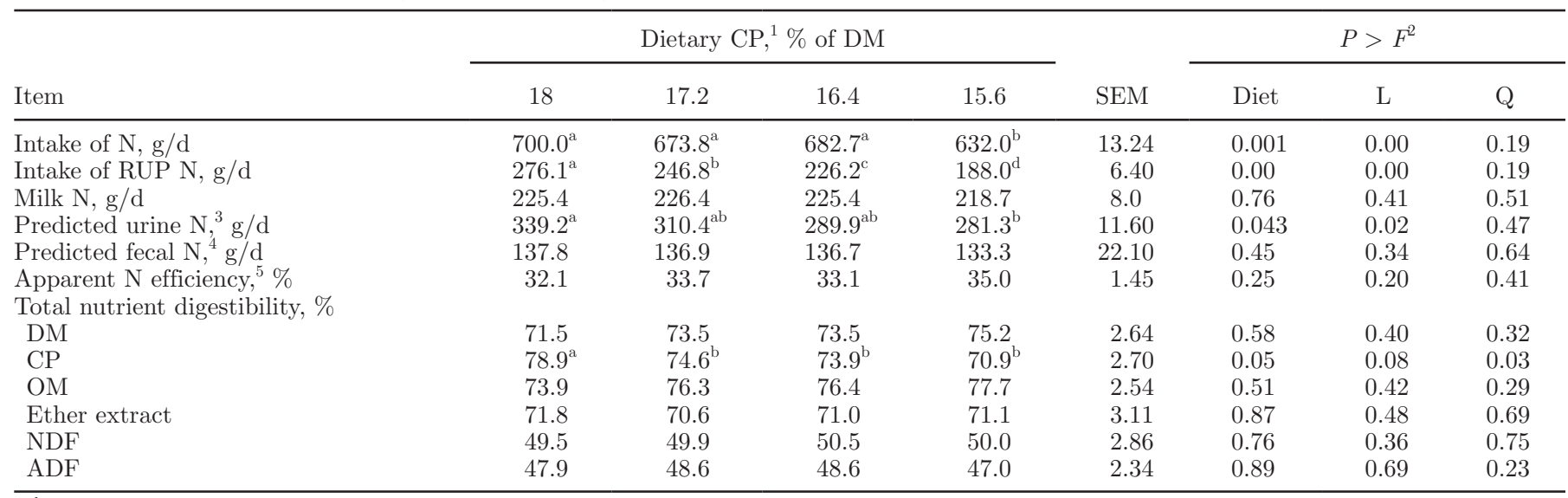

\footnotetext{
${ }^{\mathrm{a}-\mathrm{d}}$ Least squares means within a row with different superscripts differ $(P<0.05)$.

${ }^{1}$ Treatments 1 to 4 consisted of TMR containing 18, 17.2, 16.4, and $15.6 \% \mathrm{CP}$, respectively.

${ }^{2}$ Probability of a significant effect of dietary CP or of a linear (L) or quadratic (Q) effect of dietary CP.

${ }^{3}$ Predicted urine N output $=0.0283 \times$ MUN $(\mathrm{mg} / \mathrm{dL}) \times \mathrm{BW}(\mathrm{kg})($ Wattiaux and Karg, 2004)

${ }^{4}$ Predicted fecal $\mathrm{n}=\mathrm{N}$ intake - predicted urine $\mathrm{N}-$ milk $\mathrm{N}$.

${ }^{5}$ Apparent $\mathrm{N}$ efficiency $=100 \times$ milk $\mathrm{N}(\mathrm{g} / \mathrm{d}) / \mathrm{N}$ intake $(\mathrm{g} / \mathrm{d})$.
}

protein diets; however, this difference was not statistically significant.

Daily $\mathrm{N}$ intake linearly decreased with decreasing dietary CP and RUP levels, whereas fecal $\mathrm{N}$ excretion did not change (Table 7). Fecal $\mathrm{N}$ consists primarily of indigestible microbial protein produced in the rumen as well as endogenous proteins, sloughed cells from the gastrointestinal tract, and undigested feed proteins (Mason, 1969; Davidson et al., 2003). In this experiment, RUP levels were found to vary among treatment groups and decreased linearly from 18 to $15.6 \%$ dietary CP $(P<0.05)$. Because undigestible feed protein is a minor component of the total fecal $\mathrm{N}$, differences among treatments were not expected in the light of predicted values of fecal N (Davidson et al., 2003). Predicted urinary $\mathrm{N}$ excretion decreased linearly with lower dietary CP and RUP, the highest being recorded for $18 \%$ dietary $\mathrm{CP}$ and the lowest for $15.6 \%$ dietary CP $(P<0.05)$. Unlike $\mathrm{N}$ (or $\mathrm{CP})$ intake, milk $\mathrm{N}$ did not differ among treatments $(P>0.05)$ so that N utilization efficiency was numerically higher for lower CP treatments $(2,3$, and 4$)$ than that of the control group $(P>0.05)$. This may be attributed to the improved AA balance, especially Lys and Met in MP, which enhanced (Table 7) protein utilization (Schwab et al., 2007).

\section{CONCLUSIONS}

In this study, DMI, FCM, and ECM were found to increase significantly by feeding $16.4 \%$ dietary $\mathrm{CP}$, and CP digestibility was decreased by feeding $15.6 \%$ dietary CP. In addition, MUN was decreased with $15.6 \%$ di- etary CP. Based on our results, the NRC (2001) model predicts values for $\mathrm{CP}$, RUP, and MP greater than requirements. Reduced values of $\mathrm{CP}, \mathrm{RUP}$, and $\mathrm{MP}$ in the diets formulated to contain a postruminally available Lys:Met ratio of approximately 3:1 were found to have no significant effects on milk production and composition. In fact, decreasing dietary $\mathrm{CP}$ to $15.6 \%$, especially when Lys and Met were balanced, increased $\mathrm{N}$ efficiency and decreased $\mathrm{CP}$ digestibility without any detrimental effect on production performance of the animal. Therefore, the current diet evaluation model (i.e., NRC, 2001) that predicts passage of MP-AA to the small intestine in their present form is not useful for predicting the effects that changes in CP, RUP, MP-Lys, and MP-Met might have on production performance.

\section{ACKNOWLEDGMENTS}

We thank Mike Hutjens (University of Illinois, Urbana), G. M. Crovetto (Milan, Italy), and Stefania Colombini (Milan, Italy) for their invaluable comments on a first draft of this paper, and thank J. Jalilnejad (FKa Co., Isfahan, Iran) and his colleagues for the animals supplied for our experiments and their financial support. Zayande Co. (Tehran, Iran) deserves our special thanks for feed sample analysis for amino acids. The head and staff members of the Research Station of the Nutrition Laboratory at the Department of Animal Science, Isfahan University of Technology (Isfahan, Iran), are also acknowledged. Our gratitude also goes to Ezzatollah Roustazadeh and Karen Beauchemin (Agricul- 
ture and Agri-Food Canada, Lethbridge, AB, Canada) for editing the final version of this manuscript and to all others who helped us throughout this study.

\section{REFERENCES}

AOAC. 1980. Official Methods of Analysis. 13th ed. Association of Official Analytical Chemists, Washington, DC.

AOAC. 1990. Official Methods of Analysis. 15th ed. Association of Official Analytical Chemists, Arlington, VA.

AOAC International. 1996. Official Methods of Analysis. 16th ed. AOAC International, Gaithersburg, MD.

AOAC International. 2000. Official Methods of Analysis. 17th ed. AOAC International, Gaithersburg, MD.

Block, E., L. H. Kilmer, and L. D. Muller. 1981. Acid insoluble ash as a marker of digestibility for sheep fed corn plants or hay and for lactating dairy cattle fed hay ad libitum. J. Anim. Sci. 52:11641169.

Broderick, G. A. 2003. Effects of varying dietary protein and energy levels on the production of lactating dairy cows. J. Dairy Sci. 86:1370-1381.

Broderick, G. A. 2006. Nutritional strategies to reduce crude protein in dairy diets. Proc. 21st Annual Southwest Nutrition and Management Conference, Tempe, AZ. Accessed Mar. 21, 2014. http:// www.dairyweb.ca/Resources/SWNMC2006/Broderick.pdf.

Broderick, G. A., M. J. Stevenson, R. A. Patton, N. E. Lobos, and J. J. Olmos Colmenero. 2008. Effect of supplementing rumen-protected methionine on production and nitrogen excretion in lactating dairy cows. J. Dairy Sci. 91:1092-1102.

Broderick, G. A., P. Udén, M. L. Murphy, and A. Lapins. 2004. Sources of variation in rates of in vitro rumen protein degradation. J. Dairy Sci. 87:1345-1359.

Castillo, A. R., E. Kebreab, D. E. Beever, J. H. Barbi, J. D. Sutton, H. C. Kirby, and J. France. 2001. The effect of protein supplementation on nitrogen utilization in lactating dairy cows fed grass silage diets. J. Anim. Sci. 79:247-253.

Clark, J. H., T. H. Klusmeyer, and M. R. Cameron. 1992. Microbial protein synthesis and flows of nitrogen fractions to the duodenum of dairy cows. J. Dairy Sci. 75:2304-2323.

Cunningham, K. D., M. J. Cecava, T. R. Johnson, and P. A. Ludden. 1996. Influence of source and amount of dietary protein on milk yield by cows in early lactation. J. Dairy Sci. 79:620-630.

Davidson, S., B. A. Hopkins, D. E. Diaz, S. M. Bolt, C. Brownie, V. Fellner, and L. W. Whitlow. 2003. Effects of amounts and degradability of dietary protein on lactation, nitrogen utilization, and excretion in early Holstein cows. J. Dairy Sci. 86:1681-1689.

Flis, S. A., and M. A. Wattiaux. 2005. Effects of parity and supply of rumen-degraded and undegraded protein on production and nitrogen balance in Holsteins. J. Dairy Sci. 88:2096-2106.

Frank, B., and C. Swesson. 2002. Relationship between content of crude protein in rations for dairy cows and milk yield, concentration of urea in milk and ammonia emissions. J. Dairy Sci. $85: 1829-1838$
Groff, E. B., and Z. Wu. 2005. Milk production and nitrogen excretion of dairy cows fed different amounts of protein and varying of alfalfa and corn silage. J. Dairy Sci. 88:3619-3632.

Leonardi, C., M. Stevenson, and L. E. Armentano. 2003. Effect of two levels of crude protein and methionine supplementation on performance of dairy cows. J. Dairy Sci. 86:4033-4042.

Licitra, G., T. M. Hernandez, and P. J. Van Soest. 1996. Standardization of procedures for nitrogen fractionation of ruminant feeds. Anim. Feed Sci. Technol. 57:347-358.

Mason, V. C. 1969. Some observations on the distributions and origin of in sheep feces. J. Agric. Sci. 73:99-111.

Muck, R. E. 1982. Urease activity in bovine feces. J. Dairy Sci. 65:2157-2163.

Mulligan, F. J., P. Dillon, J. J. Callan, M. Rath, and F. P. O. Mara. 2004. Supplementary concentrate type affects nitrogen excretion of grazing dairy cows. J. Dairy Sci. 87:3451-3460.

NRC. 2001. Nutrient Requirements of Dairy Cattle. 7th rev. ed. Natl. Acad. Sci., Washington, DC.

Promkot, C., and M. Wanapat. 2005. Effect of level of crude protein and use of cottonseed meal in diets containing cassava chips and rice straw for lactating dairy cows. Asian-australas. J. Anim. Sci. 18:502-511.

Schwab, C. G., C. K. Bozak, N. L. Whitehouse, and M. M. A. Mesbah. 1992. Amino acid limitation and flow to the duodenum at four stages of lactation. I. Sequence of lysine and methionine limitation. J. Dairy Sci. 75:3486-3502.

Schwab, C. G., R. S. Ordway, and N. L. Whitehouse. 2003. The latest on amino acid feeding. Pages 27-41 in Proc. Southwest Nutrition and Management Conference, Phoenix, AZ.

Schwab, C. G., S. O. Ryan, and L. Nancy. 2004. Amino acid balancing in the context of MP and RUP requirements. Florida Ruminant Nutrition Symposium. Whitehouse Department of Animal and Nutritional Sciences, University of New Hampshire, Durham.

Schwab, C. G., S. E. Boucher, and B. K. Sloan. 2007. Metabolizable protein and amino acid nutrition of the cow: Where are we in 2007? Pages 121-138 in Proc. Cornell Nutr. Conf. Feed Manufacturers. http://www.dairyweb.ca/Resources/MNC2007/Schwab.pdf.

Sniffen, C. J., J. D. O'Connor, P. J. Van Soest, D. G. Fox, and J. B. Russell. 1992. A net carbohydrate and protein system for evaluating cattle diets: II. Carbohydrate and protein availability. J. Anim. Sci. 70:3562-3577.

Sutton, J. D. 1989. Altering milk composition by feeding. J. Dairy Sci. 72:2801-2814

Van Keulen, J., and B. A. Young. 1977. Evaluation of acid-insoluble ash as a natural marker in ruminant digestibility studies. J. Anim. Sci. 44:282-287.

Van Soest, P. J. 1994. Mathematical applications: Digestibility. Pages 354-370 in Nutritional Ecology of the Ruminant. 2nd ed. Comstock Publishing Associates, Ithaca, NY.

Van Soest, P. J., J. B. Robertson, and B. A. Lewis. 1991. Methods for dietary fiber, neutral detergent fiber, and nonstarch polysaccharides in relation to animal nutrition. J. Dairy Sci. 74:3583-3597.

Wattiaux, M. A., and K. L. Karg. 2004. Protein level for alfalfa and corn silage-based diets: I. Lactational response and milk urea nitrogen. J. Dairy Sci. 87:3480-3491. 